\title{
ANALYSIS OF MOTIVATIONAL FACTORS OF MSMEs ENTREPRENEURS TO BE HALALPRENEURS
}

\author{
Mumtaz Anwari \\ Universitas Indonesia \\ Sri Rahayu Hijrah Hati* \\ Universitas Indonesia
}

\begin{abstract}
This study aims to examine the motivational factors of Micro, Small and Medium Enterprises (MSMEs) entrepreneurs to become Halalpreneurs based on their religiosity, attitude (awareness of halal entrepreneurship, intrinsic motivation, effort to seek out opportunity, creativity and motivation, honesty and integrity, risk-taking attitude, relative advantage and perceived desirability), subjective norm (family support and peer influence) and perceived behavioral control (perceived feasibility, government support). Data were collected from 239 Muslim entrepreneurs who run their MSMEs. Data were then analyzed using descriptive analysis and partial least square in SmartPLS 3.0. From the result, awareness of halalpreneurship, intrinsic motivation, effort to seek out opportunity, relative advantage, perceived desirability, family support, and perceived feasibility positively are found to influence halalpreneurial propensity significantly. Meanwhile, creativity and innovation, honesty and integrity, perceived governmental support, peers influence, risk-taking attitude, and religiosity are not significant in influencing the MSMEs entrepreneur's halalpreneurial propensity.
\end{abstract}

Keywords: MSMEs; Halal; Halalpreneurship; Attitude; Subjective norms; Perceived Behavioral control.

Received: 29 January 2019

Accepted: 12 June 2020

\section{INTRODUCTION}

Entrepreneurial skill is one of the elements that determine the merits of an economy (Hechavarria, Bullough, Brush, \& Edelman, 2019; Soltanian, Zailani, Iranmanesh, \& Aziz, 2016). Entrepreneurship is important to the country's economic development because it can create jobs and other monetary benefits. Entrepreneurship is the result of a relationship of cause and effect of economic growth, technological progress, and concepts of innovation that are incorporated and related to one another (Sadri, 2012; Singh \& Gaur, 2018).

Indonesia as a country with the third-largest population in the world should pay great attention to the economic growth potential that can be created by both existing entrepreneurs and creating a new generation of entrepreneurs, especially with the ever-increasing bonus demographics obtained each year (Hoque, Mamun, \& Mamun, 2014; Suparno \& Saptono, 2018). Entrepreneurship conducted by Micro, Small, and Medium Enterprises (MSMEs) in Indonesia is very substantial,

\footnotetext{
- Corresponding author: Sri Rahayu Hijrah Hati, Management Department Faculty of Economics and Business Universitas Indonesia; Email: sri.rahay72@ui.ac.id
} 
alleviating unemployment and creating more jobs. Indonesia Ministry of Cooperatives and Small and Medium Enterprises explains the number of workers absorbed by MSMEs in Indonesia, in 2017 was $116,673,416$ workers in the MSME sector, an increase of $14.69 \%$ compared to 2012 of $101,722,458$.

Table 1: Growth of the Indonesia MSMEs Workers in 2012-2017

\begin{tabular}{|c|c|c|c|c|c|c|c|}
\hline Indicator & $\begin{array}{c}\text { Workers } \\
\text { (2012) }\end{array}$ & $\begin{array}{c}\text { Workers } \\
(2013)\end{array}$ & $\begin{array}{c}\text { Workers } \\
(2014)\end{array}$ & $\begin{array}{c}\text { Workers } \\
\text { (2015) }\end{array}$ & $\begin{array}{c}\text { Workers } \\
(2016)\end{array}$ & $\begin{array}{c}\text { Workers } \\
\text { (2017) }\end{array}$ & Growth \\
\hline $\begin{array}{l}\text { Total } \\
\text { MSMEs }\end{array}$ & $101,722,458$ & $107,657,509$ & $114,144,082$ & $123,229,386$ & $112,828,610$ & $116,673,416$ & $14.69 \%$ \\
\hline $\begin{array}{l}\text { Micro } \\
\text { Business }\end{array}$ & $94,957,797$ & $99,859,517$ & $103,624,466$ & $110,807,864$ & $103,839,015$ & $107,232,992$ & $12.92 \%$ \\
\hline $\begin{array}{l}\text { Small } \\
\text { Business }\end{array}$ & $3,919,992$ & $4,353,970$ & $5,570,231$ & $7,307,503$ & $5,402,073$ & $5,704,321$ & $45.51 \%$ \\
\hline $\begin{array}{l}\text { Medium } \\
\text { Business }\end{array}$ & $2,844,669$ & $3,262,023$ & $3,949,385$ & $5,114,020$ & $3,587,522$ & $3,736,103$ & $31.33 \%$ \\
\hline $\begin{array}{l}\text { Large } \\
\text { Business }\end{array}$ & 2.891 .224 & 3.150 .645 & 3.537 .162 & 4.194 .051 & 3.444 .746 & 3.586 .769 & \\
\hline
\end{tabular}

Source: Micro, Small, Medium Enterprises and Large Enterprises in 2012-2017 Ministry of Cooperatives and Small and Medium Enterprises of the Republic of Indonesia

MSMEs also play an important role in Indonesia's Gross Domestic Product (GDP), recorded in 2017 MSMEs contributed $60 \%$ or IDR7,704.6 trillion contributions to GDP with a growth rate of 9.92\% for the year 2016-2017. The total contribution given by MSMEs to GDP was accumulated from various sectors of MSMEs (Trade, processing, agriculture, plantation, livestock, fishery, Service sector), In addition, MSMEs contributed export volume up to $14,17 \%$ or equivalent to IDR 298.28 trillion of total national exports in 2017 (Perkembangan Data Usaha Mikro, Kecil, Menengah (UMKM) Dan Usaha Besar UBB) Tahun 2016 - 2017, 2019).

The global halal market potential in 2023 is $\$ 1,863$ billion for food, \$361 billion for fashion, \$274 billion for tourism, $\$ 90$ Billion for cosmetics, $\$ 131$ billion for pharmaceuticals, $\$ 288$ trillion for media and recreation, and \$3,809 billion for financial markets industry (Thomson Reuters, 2018). With a total Muslim population of 1.8 billion and total spending estimated at US\$2.1 trillion in 2017, the Islamic economy is predicted to continue its steady growth (Thomson Reuters, 2018).

In Indonesia itself, the total number of the Muslim population is estimated at 229 million or around $87.20 \%$ of its total population ("Muslim Majority Countries 2019," 2019). The high number of Muslim populations in the country has opened a wide opportunity for the entrepreneurs to tap the potential market especially for those focusing on the halal industry. Despite its position as the largest Muslim country in the world, Indonesia is currently only become a target market for halal products, instead of becoming the key player in the halal industry (Karimah, 2019). For the halal food sector and pharmaceuticals, for example, Indonesia not even listed among the top ten Halal food producers (Thomson Reuters, 2018). The Indonesian Islamic Institute for Food and Drug Administration stated that there is only $59 \%$ of businesses in the pharmaceutical, food, and cosmetic industries have halal certification. The above phenomenon implies that there is still a wide opportunity for Muslim entrepreneurs to serve the untapped halal market in Indonesia. As the total number of workers absorbed by the MSMEs is consistently to be higher $(116,673,416$ workers) 
compare to the large company (3.586.769 workers), the MSMEs has a really important role for or economic growth and social inclusion in Indonesia (Organisation for Economic Co-operation and Development, 2018). Based on the above arguments, the study aims to examine the motivational factors of Micro, Small and Medium Enterprises (MSMEs) entrepreneurs to become Halalpreneurs. As the halal issue cannot be separated from the role of religion, the current study will also examine the role of religiosity in influencing the MSMEs entrepreneur to become halalpreneur.

\section{LITERATURE REVIEW}

\subsection{Entrepreneurship, Small and Medium Enterprises}

Entrepreneurship is a process of creating new things by considering the risks and benefits (Hisrich, Peters, \& Shepherd, 2002). Entrepreneurship itself can be classified in its purpose based on needs and opportunities. An entrepreneur can also be pushed into entrepreneurship because of the lack of choice to survive or to be drawn out into entrepreneurship to pursue a business opportunity (Acs, Desai, \& Hessels, 2008; Edoho, 2016).

SMEs are a concept that is related to entrepreneurship. SMEs are an innovative source of ideas in an economy and have become a major source of employment in many developed economies, as one of the increasing pressures on multi-national companies. Small and medium enterprises are often defined as a body that has deficiencies, both in the capital and human resources, management structures, and access to global markets, Sometimes people often see MSMEs in terms of these shortcomings because of their relatively small size compared to multi-national companies (Carson \& Gilmore, 2000).

\subsection{Halalpreneurship}

Individuals who are interested in innovating and utilizing all opportunities that can be optimized on the development of halal business, also known as halalpreneurs or kosher entrepreneurs (Soltanian et al., 2016). Halal entrepreneurship is a new concept that links halal development to executed business activities as halalpreneurial, The development of halal entrepreneurship has changed in how society sees business activity and its impact on consumer demand for halal products, For example, a business is required to have a balance between profit-seeking activities and the fulfillment of halal requirements through halal operations (Vargas-Hernández, Noruzi, \& Sariolghalam, 2010).

However, there is still confusion because halal entrepreneurship is a new concept under the umbrella of the concept of entrepreneurship, In explaining the concept, some academics call it also the term "Halal-Minded Entrepreneurship"(Baharuddin, Kassim, Nordin, \& Buyong, 2015). According to Soltanian et al. (2016), several factors influence an individual to become halalpreneurs, in this study is called as halalpreneurial propensity. The factors that influence the entrepeneurs' halalpreneurship according to Soltanian et al. (2016), are attitudes, subjective norms and perceived behavioral control. 


\subsubsection{Attitude}

Attitude is the extent to which a person has an assessment that is favorable or not favorable to a behavior (Ajzen, 1991). Attitude is a factor that influences behavioral intention in TRA (Theory of reasoned action) and TPB (Theory of Planned Behavior), Many studies confirm that attitude has a significant impact on entrepreneurial intention (Rahman \& Mohamed, 2011). Based on Soltanian et al. (2016) research, the halalpreneurial propensity of the entrepreneur is influenced by attitudes. The attitudes itself consist of halal awareness (Baharuddin et al., 2015) motivations on halal business (Talib, Bakar, \& Too, 2019), effort to seek out opportunity (Rahman \& Mohamed, 2011), creativity and innovation (Zampetakis \& Moustakis, 2006), honesty and integrity (Othman, Ahmad, $\&$ Zailani, 2009), risk-taking attitude (Bustamam, 2012), relative advantage (Soltanian et al., 2016) and perceived desirability (Guerrero, Rialp, \& Urbano, 2008).

Many studies have shown the importance of awareness in developing entrepreneurship in society (Fayolle \& Gailly, 2008). The awareness about entrepreneurship makes the entrepreneurial venue become a rational and viable option of occupation (Liñán, 2007). In regards to halal business, Soltanian et al. (2016) found that the awareness about the halal entrepreneurship significantly influences the halalpreneurial propensity. Therefore:

\section{$H_{1}$ : Awareness of halal entrepreneurship significantly and positively affects halalpreneurial propensity}

Intrinsic motivation refers to the pleasure of carrying out a certain activity, which belongs to the internal sphere of the individual (Guzmán \& Javier Santos, 2001). In an academic entrepreneurial context, intrinsic motivation is found to have a significant impact on academic entrepreneurial intention (Antonioli, Nicolli, Ramaciotti, \& Rizzo, 2016), and so does in the Islamic halal business context (Soltanian et al., 2016). Thus:

\section{$\mathrm{H}_{2}$ : Intrinsic motivation significantly and positively influences the tendency of halalpreneurial propensity}

The effort to seek out opportunity refers to can be classified into three categories (Dyer, Gregersen, $\&$ Christensen, 2008). First is in connecting known products with existing demand to exploit a previously recognized opportunity. Second is by starting with known supply and proceeds in search of an unknown demand, or from a known demand that motivates the search for an unknown supply. The third is by creating non-existing supply and demand. Currently, there is a high demand for halal products (Thomson Reuters, 2018). Thus, there is a high potential for the entrepreneur including those who run MSMEs to fulfill the existing demand on halal products. The previous study in the context of halal business found an effort to seek out opportunity is significant influences the Muslim entrepreneur to set up a halal business (Soltanian et al., 2016). Therefore:

\section{H3: Effort to seek out opportunity significantly and positively affects halalpreneurial propensity}

Creativity is an attitude that refers to the ability to generate new ideas by combining, changing, or reapplying existing ideas (Okpara, 2007). The existence of creativity will enable the entrepreneur to create innovation (Drucker, 2014). Creativity and innovation are also required in running the 
SMEs. The previous study shows that creativity and innovation are found to have a significant impact on the financial performance of SMEs in the halal food sector (Fard \& Amiri, 2018). Thus:

\section{H4: Creativity and innovation significantly and positively affects halalpreneurial propensity}

Trustworthiness is one of the key success factors of an entrepreneur (Rhee \& White, 2007). Trustworthiness reflects the ability of an individual to maintain a standard of honesty and integrity, which also a part of the emotional intelligence of an entrepreneur (Rhee \& White, 2007). Currently, there is raising awareness on the ethical and socially responsible practices not only by a large corporation but also by SME (Ahmad \& Ramayah, 2012). The concept of honesty and integrity are the values that should also be held by Muslim entrepreneurs as Islam emphasize honest dealing in a business transaction (Akbar, 1993). Therefore, in the halal business context, it is expected that:

\section{$H_{5}:$ Honesty and integrity significantly and positively influence halalpreneurial propensity}

Risk-taking is an important aspect of running a business (Tyszka, Cieślik, Domurat, \& Macko, 2011). Macko \& Tyszka (2009) found that the entrepreneur tends to take risk more frequently than non-entrepreneur. Besides, entrepreneur's choice of the risky situation is usually influenced by certain norms (Tyszka \& Zaleskiewicz, 2006). Therefore, it is expected that the Muslim entrepreneur will take a risk which is related to the Islamic norm, that is to embed halal norm to its business. Thus:

\section{$H_{6}:$ Risk-taking attitude significantly and positively affects halalpreneurial propensity}

Relative advantage is the degree to which an innovation is considered as being better than the idea it supersedes (Wang \& Lin, 2016). The relative advantage concept is usually discussed in relation to technology (Moghavvemi, Hakimian, \& Tengk Feissal, 2012). According to (Ireland, Hitt, \& Sirmon, 2003), SMEs face some difficulty in achieving competitive advantage compare to relative advantage. Therefore, the SMEs need to be able to give more value to its customers better than its rivals so that it can have what so-called as a relative advantage. In regards to entrepreneurship in the Islamic context, the halal concept can become a relative advantage exploited by the Muslims entrepreneurs (Soltanian et al., 2016). Therefore:

\section{H7: Relative advantage significantly and positively affects halalpreneurial propensity}

Perceived desirability reflects a person's evaluation of his/her ability to manage the business startup process successfully (Kuehn, 2008). Fitzsimmons \& Douglas (2011) found that perceived desirability significantly influences the entrepreneurial intention. The arguments are supported by Soltanian et al. (2016) who found that perceived desirability significantly influence the Muslim entrepreneur halalpreneurial propensity. Therefore:

\section{$H_{8}:$ Perceived desirability significantly and positively affects halalpreneurial propensity}




\subsection{Subjective Norm}

Explains that subjective norms are "social pressure to do or not to do a behavior" (Ajzen, 1991). Subjective norm is also refers to the opinion, views, and influence of the immediate environment (family, friends, and relatives) can affect the intention of a person. Bellò, Mattana, \& Loi (2018) argue that having a role model, both parents and relatives who are entrepreneurs is a positive relationship with entrepreneurial intentions. Encouragement from relatives and families to become entrepreneurs strengthen the positive relationship between creativity and entrepreneurial intention, and entrepreneurial-efficacy acts as a mediator by explaining the mechanism environment that connects creativity to entrepreneurial intentions. The ideas are supported by Carr \& Sequeira (2007), who found significant direct and indirect effects of prior family business exposure on entrepreneurial intent. To date in Indonesia, there is only limited Islamic family business that applies Islamic values including halal concept (Dewi \& Dhewanto, 2012). However, it is expected that in the context of Indonesian MSMEs, we expect that:

\section{H9: Family support significantly and positively affects halalpreneurial propensity}

In addition to family roles, the role of colleagues is also important for young people because it can stimulate the development of entrepreneurial identity by giving influence in the form of selfrecognition to the surrounding environment (Falck, Heblich, \& Luedemann, 2012). Soltanian et al. (2016) found that peer influence has a positive impact on halalpreneurial propensity. Thus, in the context of Indonesian MSMEs, it is expected that:

\section{$H_{10}$ : Peer influence significantly and positively affects halalpreneurial propensity}

\subsection{Perceived Behavioral Control}

Ajzen (1991) explains that perceived behavioral control can be determined by one's confidence in a force that is both situational and internal factors, can accommodate that behaviour. Shapero \& Sokol (1982) explained that perceived feasibility is a construction of perceived behavior control and can be defined as a person's belief in capability and its capacity to become an entrepreneur. (Krueger, 1993) found that prior entrepreneurial exposure has an impact on the perceptions of new venture feasibility. In the context of halal business, Soltanian et al. (2016) found that perceived feasibility positively affects halalpreneurial propensity. Thus, in the MSMEs context, it is expected that:

\section{$H_{11}$ : Perceived feasibility significantly and positively affects halalpreneurial propensity}

At the national level, the government needs to increase the participation of MSME entrepreneurs in Halalpreneurship by developing effective and comprehensive policy strategies. The Muslim entrepreneurs also perceive that the government should play a significant role in encouraging MSME players to enter the halal industry (Soltanian et al., 2016). Thus:

\section{H12: Perceived governmental support significantly and positively affects halalpreneurial propensity}




\subsection{Religiosity}

Previous studies had discussed the relationship between religiosity on entrepreneurial behavior (e.g., Balog, Baker, \& Walker, 2014). Bellu \& Fiume (2004), found that religiosity is found to influence the entrepreneurial success significantly. According to Gümüsay (2015), Islam is an entrepreneurial religion in the light that it supports and promotes entrepreneurial activity. Riaz, Farrukh, Rehman, \& Ishaque (2016) had found a significant impact of religion on entrepreneurial intention of Pakistanese. Therefore, it is expected that:

\section{H13: Religiosity significantly and positively affects halalpreneurial propensity}

Based on the above arguments, the following research framework is developed:

Figure 1: Research Framework

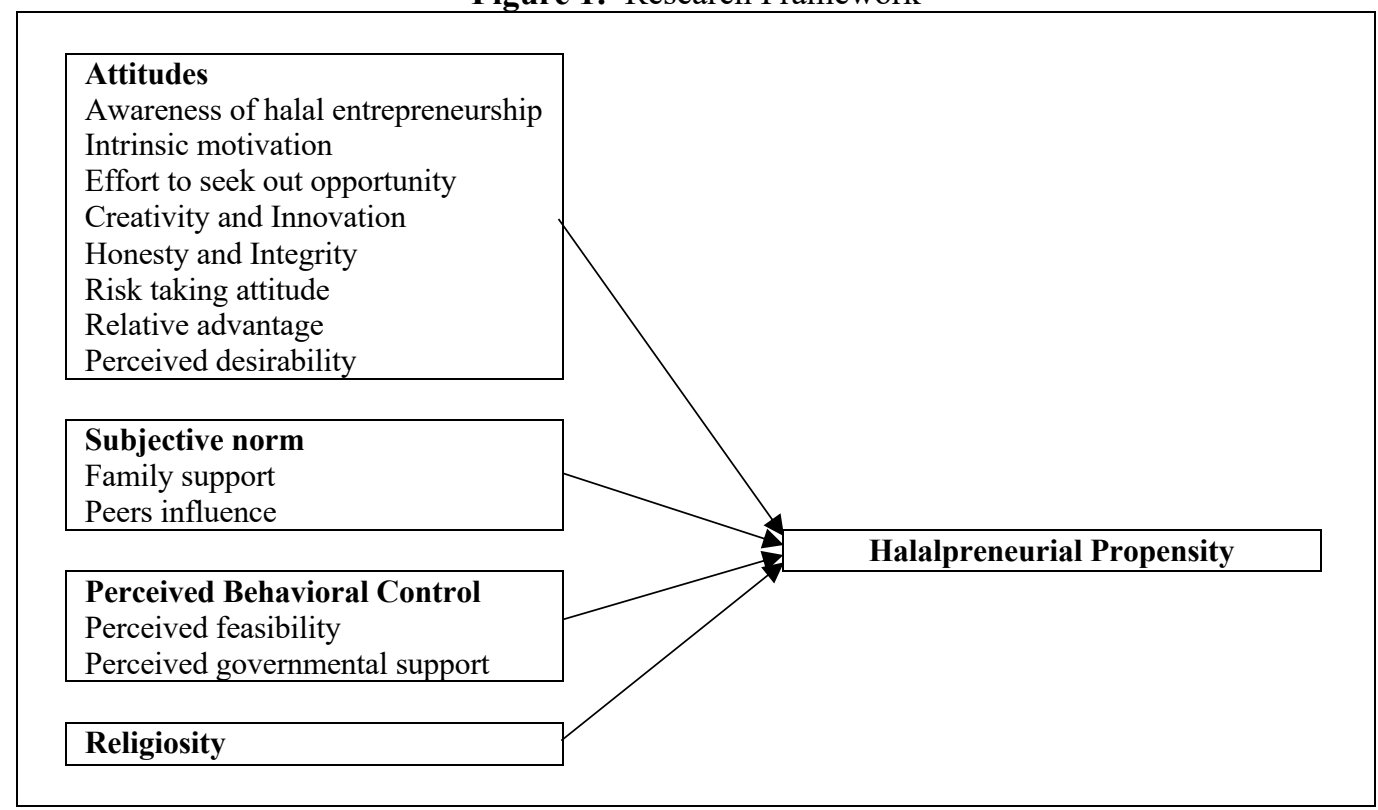

Source: Author, modified from Soltanian et al., (2016)

The above research framework is a replication and adaptation of the Soltanian et al. (2016) study's in the sense that a new variable - religiosity is added to the model as the current study is conducted in the context of Islamic MSMEs. Soltanian et al. (2016) model is replicated as its model comprehensively examines many attitudinal, subjective norm, and perceived behavioral subvariables. 


\section{RESEARCH METHODOLOGY}

The data was collected from an offline survey distributed to several MSMEs communities in Indonesia. A six-point Likert scale questionnaire is applied in the study. The survey instruments are adapted from Soltanian et al. (2016) for the awareness of halal entrepreneurship; intrinsic motivation; effort to seek out opportunity; creativity and innovation; honesty and integrity; risktaking attitude; relative advantage; perceived desirability; family support; peer influence; perceived feasibility; perceived governmental support and halalpreneurship propensity. The religiosity measurement is adapted from (Abou-Youssef, Kortam, Abou-Aish, \& El-Bassiouny, 2015).

Before the main data collection, pre-test was conducted to 30 respondents who owned the MSMEs in Jakarta Greater Area. The MSMEs definition used in the study is based on MSME Law 20/2008 (see Table 1).

Table 1: MSMEs Categorization in Indonesia

\begin{tabular}{|c|c|c|}
\hline Category & Assets & Annual Revenue \\
\hline Micro & up to IDR 50,000,000 & up to IDR $300,000,000$ \\
\hline Small & $\begin{array}{l}\text { over IDR 50,000,000 ( } 50 \text { million } \\
\text { rupiah) to IDR } \\
500,000,000 \text { ( } 500 \text { million } \\
\text { rupiah) }\end{array}$ & $\begin{array}{l}\text { over IDR } 300,000,000(300 \\
\text { million) to IDR } 2,500,000,000 \\
\text { ( } 2.5 \text { billion rupiah) }\end{array}$ \\
\hline Medium & $\begin{array}{l}\text { over IDR 500,000,000 ( } 500 \\
\text { million) to IDR } \\
10,000,000,000 \text { ( } 10 \text { billion } \\
\text { rupiah) }\end{array}$ & $\begin{array}{l}\text { more than IDR } 2,500,000,000 \\
(2.5 \\
\text { billion rupiah) to IDR } \\
50,000,000,000 \text { ( } 50 \text { billion } \\
\text { rupiah) }\end{array}$ \\
\hline
\end{tabular}

The data was collected using a purposive sampling technique. The final data was collected from 239 Muslim entrepreneurs who run their MSMEs. The data was analyzed using Partial Least Square (PLS).

A validity analysis was conducted on the survey questionnaire. All variables have met the validity requirements with the Average Variance Expected (AVE) value above 0.5 (Kline, 2011). In terms of reliability, all variables have also met the criteria with Composite Reliability (CR) values above 0.60 (Fornell \& Larcker, 1981).

Table 2: Results of Validity \& Reliability Analysis

\begin{tabular}{lcccc}
\hline \hline \multicolumn{1}{c}{ Variable } & $\begin{array}{c}\text { Average } \\
\text { Variance } \\
\text { Extracted (AVE) }\end{array}$ & Conclusion & $\begin{array}{c}\text { Composite } \\
\text { Reliability (CR) }\end{array}$ & Conclusion \\
\hline $\begin{array}{l}\text { Awareness } \\
\text { Towards Halal }\end{array}$ & 0.625465505 & Valid & 0.891061264 & Reliable \\
$\begin{array}{l}\text { Entrepreneurship } \\
\text { Intrinsic } \\
\text { Motivation }\end{array}$ & 0.523803663 & Valid & 0.868096119 & Reliable
\end{tabular}




\begin{tabular}{lcccc}
\hline \multicolumn{1}{c}{ Variable } & $\begin{array}{c}\text { Average } \\
\text { Variance } \\
\text { Extracted (AVE) }\end{array}$ & Conclusion & $\begin{array}{c}\text { Composite } \\
\text { Reliability (CR) }\end{array}$ & Conclusion \\
\hline $\begin{array}{l}\text { Effort to Seek Out } \\
\text { Opportunity } \\
\begin{array}{l}\text { Creativity and } \\
\text { Innovation }\end{array}\end{array}$ & 0.692968014 & Valid & 0.899922032 & Reliable \\
$\begin{array}{l}\text { Honesty and } \\
\text { Integrity }\end{array}$ & 0.710236368 & Valid & 0.880277732 & Reliable \\
$\begin{array}{l}\text { Risk Taking } \\
\text { Attitude }\end{array}$ & 0.578639035 & Valid & 0.804515921 & Reliable \\
$\begin{array}{l}\text { Relative } \\
\text { Advantage }\end{array}$ & 0.758886555 & Valid & 0.862818504 & Reliable \\
$\begin{array}{l}\text { Perceived } \\
\text { Desirability }\end{array}$ & 0.653630057 & Valid & 0.849049358 & Reliable \\
$\begin{array}{l}\text { Family Support } \\
\text { Peers Influence }\end{array}$ & 0.708056372 & Valid & 0.878938516 & Reliable \\
$\begin{array}{l}\text { Perceived } \\
\text { Feasibility }\end{array}$ & 0.589817243 & Valid & 0.945590098 & Reliable \\
$\begin{array}{l}\text { Perceived } \\
\text { Governmental }\end{array}$ & 0.765558606 & Valid & 0.750806662 & Reliable \\
$\begin{array}{l}\text { Support } \\
\text { Halalpreneurial }\end{array}$ & 0.685667841 & Valid & 0.866867729 & Reliable \\
$\begin{array}{l}\text { Propensity } \\
\text { Religiosity }\end{array}$ & 0.687846488 & Valid & 0.867304364 & Reliable \\
\hline \hline
\end{tabular}

\section{RESULTS}

\subsection{Sample Description}

Out of 239 MSME entrepreneurs, most of them were female (58.2\%), 21-30 years old (44.8\%), high school graduates $(60.7 \%)$, single $(73.22 \%)$, lived in Jakarta $(30.96 \%)$, had business in food and beverage sector $(40.17 \%)$, classified their business in micro category and fell under micro business category $(84.94 \%)$.

Table 3: MSME Entrepreneurs \& Enterprise Characteristic

\begin{tabular}{lccc}
\hline \hline & Variable & Frequency & Percentage (\%) \\
\hline Gender & Male & 100 & 41.8 \\
& Female & 139 & 58.2 \\
\hline Age & $<20$ years old & 80 & 33.47 \\
& $21-30$ years old & 107 & 44.77 \\
& $31-40$ years old & 20 & 8.37 \\
& >40 years old & 32 & 13.39 \\
\hline Education & Elementary & 1 & 0.42 \\
& Junior high & 3 & 1.26 \\
& Senior high & 145 & 60.67 \\
& Undergraduate & 81 & 33.89 \\
& Postgraduate & 9 & 3.77 \\
\hline
\end{tabular}




\begin{tabular}{|c|c|c|c|}
\hline \multicolumn{2}{|c|}{ Variable } & \multirow{2}{*}{$\begin{array}{c}\text { Frequency } \\
175\end{array}$} & \multirow{2}{*}{$\begin{array}{c}\text { Percentage (\%) } \\
73.22\end{array}$} \\
\hline Marital Status & Single & & \\
\hline & Married & 64 & 26.77 \\
\hline \multirow[t]{7}{*}{ City } & Jakarta & 74 & 30.96 \\
\hline & Depok & 72 & 30.12 \\
\hline & Bogor & 21 & 8.78 \\
\hline & Bekasi & 17 & 7.11 \\
\hline & Tangerang & 12 & 5.02 \\
\hline & Malang & 5 & 2.09 \\
\hline & Others & 23 & 15.89 \\
\hline \multirow[t]{9}{*}{ Business Sector } & Food & 96 & 40.17 \\
\hline & Fashion & 62 & 25.94 \\
\hline & Trading & 17 & 7.11 \\
\hline & Crafting & 12 & 5.02 \\
\hline & Services & 12 & 5.02 \\
\hline & Education & 6 & 2.51 \\
\hline & Beauty & 6 & 2.51 \\
\hline & Technology & 9 & 3.77 \\
\hline & Others & 19 & 7.95 \\
\hline \multirow[t]{3}{*}{ Age of 1131nterprise } & $<1$ year & 118 & 49.37 \\
\hline & $1-3$ years & 77 & 32.21 \\
\hline & >3years & 44 & 18.41 \\
\hline \multirow[t]{3}{*}{ MSME category } & Micro & 203 & 84.94 \\
\hline & Small & 28 & 11.72 \\
\hline & Medium & 8 & 3.35 \\
\hline Total & & 239 & 100 \\
\hline
\end{tabular}

As explained earlier, the partial least square method is used. This technique can simultaneously assess the measurement model and the structural model by minimizing the error variance. The researchers bootstrapped 500 subsamples as recommended by Hair, Sarstedt, Hopkins, \& Kuppelwieser (2014) to obtain optimal results and use a 5\% confidence level and one-tailed.

Table 2: Hypothesis Testing Analysis

\begin{tabular}{|c|c|c|c|}
\hline Variable & Coefficient & T-Statistics & Conclusions \\
\hline $\begin{array}{l}\mathrm{H}_{1} \text { : Awareness of halal entrepreneurship } \rightarrow \\
\text { halalpreneurial propensity }\end{array}$ & 0.099 & 1.928 & Accepted \\
\hline $\mathrm{H}_{2}$ : Intrinsic motivation $\rightarrow$ halalpreneurship propensity & 0.184 & 2.546 & Accepted \\
\hline $\begin{array}{l}\mathrm{H}_{3} \text { : Effort to seek out opportunity } \rightarrow \text { halalpreneurial } \\
\text { propensity }\end{array}$ & 0.206 & 2.714 & Accepted \\
\hline $\begin{array}{l}\mathrm{H}_{4:} \text { Creativity and innovation } \rightarrow \text { halalpreneurial } \\
\text { propensity }\end{array}$ & -0.005 & 0.092 & Rejected \\
\hline $\begin{array}{l}\mathrm{H}_{5}: \text { Honesty and integrity } \rightarrow \text { halalpreneurial } \\
\text { propensity }\end{array}$ & 0.007 & 0.118 & Rejected \\
\hline $\mathrm{H}_{6}:$ Risk-taking attitude $\rightarrow$ halalpreneurial propensity & 0.087 & 1.382 & Rejected \\
\hline $\mathrm{H}_{7}$ : Relative advantage $\rightarrow$ halalpreneurial propensity & 0.110 & 1.951 & Accepted \\
\hline $\mathrm{H}_{8}$ : Perceived desirability $\rightarrow$ halalpreneurial propensity & 0.138 & 1.680 & Accepted \\
\hline $\mathrm{H}_{9}$ : Family support $\rightarrow$ halalpreneurial propensity & 0.146 & 1.983 & Accepted \\
\hline
\end{tabular}




\begin{tabular}{|c|c|c|c|}
\hline $\mathrm{H}_{10}:$ Peer influence $\rightarrow$ halalpreneurial propensity & 0.008 & 0.128 & Rejected \\
\hline $\mathrm{H}_{11}$ : Perceived feasibility $\rightarrow$ halalpreneurial propensity & 0.227 & 3.565 & Accepted \\
\hline $\begin{array}{l}\mathrm{H}_{12} \text { : Perceived governmental support } \rightarrow \\
\text { halalpreneurial propensity }\end{array}$ & 0.067 & 1.411 & Rejected \\
\hline $\mathrm{H}_{13}$ : Religiosity $\rightarrow$ halalpreneurial propensity & -0.051 & 1.141 & Rejected \\
\hline
\end{tabular}

Based on the PLS results, $\mathrm{H}_{1}$, which examines the impact of awareness of the halal entrepreneurship on halalpreneurial propensity was not supported (path coefficient=-0.099; t-statistics $=1.928$ ). $\mathrm{H}_{2}$, which proposes the significant and positive of intrinsic motivation on halalpreneurial propensity (path coefficient $=0.184$; $\mathrm{t}$-statistics $=2.546$ ) and $\mathrm{H}_{3}$, which proposes significant and positive impact of the effort to seek out the opportunity on halalpreneurship opportunity (path coefficient $=0.206$; t-statistics $=2.714$ ) were also supported. In contrast, $\mathrm{H}_{4}, \mathrm{H}_{5}, \mathrm{H}_{6}$ which tested the impact of creativity and innovation (path coefficient $=-0.0005 ; \mathrm{t}$-statistics $=0.0092$ ), honesty and integrity (path coefficient $=0.007 ;$ t-statistics $=0.118$ ) and risk-taking attitude (path coefficient $=0.087 ; \mathrm{t}$ statistics $=1.382$ ) were rejected. While $\mathrm{H}_{7}$ (path coefficient $=0.110$; t-statistics $=1.951$ ) and $\mathrm{H}_{8}$ (path coefficient $=0.138$; $t$-statistics $=1.680$ ) which tested the significant and positive impact of relative advantage and perceived desirability were accepted. Concerning subjective norm variables, it is only $\mathrm{H}_{9}$ which tested the positive influence of family support on halalpreneurial propensity (path coefficient $=0.146$; $\mathrm{t}$-statistics $=1.938$ ), which was supported while $\mathrm{H}_{10}$ which tested the significant and positive impact of peer influence (path coefficient $=0.008$; t-statistics $=1.280$ ) was rejected. A similar pattern also found in the perceived behavioral control; there was only one hypothesis, $\mathrm{H}_{11}$ which tested positive impact perceived feasibility (path coefficient $=0.227$; t-statistics $=3.565$ ) which was supported, while $\mathrm{H}_{12}$ which tested the impact of perceived governmental support on halalpreneur propensity (path coefficient $=0.067$; t-statistics $=1.411$ ) which was rejected. The additional hypotheses which tested the influence of religiosity on halalpreneur propensity were rejected (path coefficient $=-0.051$; t-statistics $=1.141$ ).

\section{DISCUSSION}

Based on the above hypotheses testing awareness of halal entrepreneurship is significant in influencing the MSMEs entrepreneurship. The results support the study of the previous study conducted both in conventional (Fayolle \& Gailly, 2008) and halal business (Soltanian et al., 2016). As the awareness of entrepreneurship, in general, can give more job alternatives to society (Liñán, 2007), the awareness of halal entrepreneurship should be raised either through education or governmental campaigns.

The study also found the significant impact of intrinsic motivation on halalpreneurship propensity. The study supports the finding of Soltanian et al. (2016). The results indicate that the Muslim entrepreneurs found some pleasure in running the halal business, which gives positive influence to their internal sphere of the individual, as suggested by Guzmán \& Javier Santos, (2001).

The effort to seek out opportunities is also significantly influencing the Muslims entrepreneur's halalpreneurship propensity. The results may imply that the Muslim entrepreneur tries to supply the growing potential demand for halal products (Thomson Reuters, 2018). The study supports the finding of Soltanian et al. (2016). 
The previous study found that creativity and innovation are found to have a significant impact on the performance of SME in the halal food sector (Fard \& Amiri, 2018). However, the current study found no support for the hypotheses which tested the significant impact of creativity and innovation on halalpreneurship propensity. The results indicate that the Muslims' entrepreneurs halalpreneurship propensity may come out not as a result of their internal creativity but may be driven by other most significant external factors which in the current study may be driven more significantly by the availability of the opportunity which in this study has the highest t-value and path coefficient for the attitude variables. The result aligns with the result of Soltanian et al. (2016). Other studies have suggested that creativity \& innovations can generally be regarded as naïve concepts when associated with the concept of entrepreneurship (Bjørner, Kofoed, \& BruunPedersen, 2012; Edwards-Schachter, García-Granero, Sánchez-Barrioluengo, Quesada-Pineda, \& Amara, 2015)

Even though the concept of honesty and integrity are the values that should be held by the Muslim entrepreneurs as Islam emphasizes an honest dealing in a business transaction (Akbar, 1993), the study found an insignificant impact of honesty and integrity on halalpreneurship propensity of Muslim MSMEs entrepreneur.

As explained earlier, risk-taking is an important aspect of running a business (Tyszka et al., 2011). However, the current study found that it is not the Muslims entrepreneurs' risk-taking attitude, which makes them willing to set up business in the halal sector. The study supports the findings of Soltanian et al. (2016).

In regard to relative advantage and perceived desirability, the study found supports for both variables on halalpreneurship propensity. The results are align with (Soltanian et al., 2016) findings. As discussed before, Ireland, Hitt, \& Sirmon (2003) explained that SMEs face some difficulty in achieving competitive advantage compare to relative advantage. Thus, the significant impact of relative advantage on halalpreneurship propensity implies that the Muslim entrepreneurs may see that they can develop the relative advantage as they have more knowledge about the needs of their customers better than Non-Muslim customers so that they can give more value to its customers better than its rival. Besides, the Muslim MSMEs entrepreneur also has positive perceived desirability in which they believe that they can manage the business start-up process successfully, as explained by Kuehn (2008). The results also support Fitzsimmons \& Douglas (2011) study which was conducted in a conventional business context.

In terms of subjective norms, it is only family supports which was significantly influenced MSMEs' halalpreneurial propensity while peer influence was not significant. The results may indicate that the Muslim MSMEs entrepreneur may get support from both parents or relatives or having them as a role model in entrpreneurship as also found in the non-halalpreneurial research (Bellò et al., 2018; Carr \& Sequeira, 2007).

In regards to perceived behavioral norms, there is also some difference found in the results of this study with (Soltanian et al., 2016) studies. While the current study support (Soltanian et al., 2016) perceived feasibility impact on halalpreneurship propensity. The result of perceived governmental support found no support for (Soltanian et al., 2016) study. The result indicates that although the 
Muslims entrepreneur has a belief in his/her capability and capacity to become an entrepreneur, they don't see that government support is insufficient for MSMEs development.

As for religiosity, there was no significant effect on halalpreneurial propensity. This can imply that it is the non-religion factors that drive Muslim MSMEs entrepreneurs to enter halal business. The economic opportunity offers by the growing halal industry itself is seen as a promising potential in terms of market share that can be achieved by halal business.

\section{CONCLUSION, LIMITATIONS AND FUTURE RESEARCH DIRECTIONS}

The current research found that in the context of Halal MSMEs in Indonesia, perceived behavioral control factor, which is represented by perceived feasibility, becomes the most influential factor to halalpreneurial propensity. The following most influential factor to halalpreneurial propensity comes from the attitudinal factor which is represented by an effort to seek out opportunity, intrinsic motivation, perceived desirability, relative advantage, and awareness of halalpreneurship. The only significant factor from the subjective norms variable is family support, while additional variables tested in the study- religiosity has no significant impact on halalpreneurial propensity.

Currently, there is still a very low entrepreneurship ratio to the total population in Indonesia despite the ability of the MSMEs to absorb more workers. Thus, the Indonesian government should give more support especially to the development of Halal MSMEs as the entrepreneurs perceived the support from the government is still very low.

The study only examines halal propensity as the dependent variable of the MSMEs rather than more objective performance, such as the financial performance of the organization. Therefore, the future researcher should consider testing the effect of the independent variables listed in the current study on MSMEs financial performance.

\section{REFERENCES}

Abou-Youssef, M. M. H., Kortam, W., Abou-Aish, E., \& El-Bassiouny, N. (2015). Effects of religiosity on consumer attitudes toward Islamic banking in Egypt. International Journal of Bank Marketing, 33(6), 786-807. doi: 10.1108/IJBM-02-2015-0024

Acs, Z. J., Desai, S., \& Hessels, J. (2008). Entrepreneurship, economic development and institutions. Small Business Economics, 31(3), 219-234. doi: 10.1007/s11187-008-9135-9

Ahmad, N. H., \& Ramayah, T. (2012). Does the Notion of 'Doing Well by Doing Good' Prevail Among Entrepreneurial Ventures in a Developing Nation? Journal of Business Ethics, 106(4), 479-490. doi: 10.1007/s10551-011-1012-9

Ajzen, I. (1991). The theory of planned behavior. Organizational Behavior and Human Decision Processes, 50(2), 179-211. doi: 10.1016/0749-5978(91)90020-T

Akbar, M. (1993). Ideology, Environment and Entrepreneurship: Typologies from Islamic Texts and History. The Journal of Entrepreneurship, 2(2), 135-154. doi: 10.1177/097135579300200201

Antonioli, D., Nicolli, F., Ramaciotti, L., \& Rizzo, U. (2016). The Effect of Intrinsic and Extrinsic Motivations on Academics' Entrepreneurial Intention. Administrative Sciences, 6(4), 15. doi: $10.3390 /$ admsci6040015 
Baharuddin, K., Kassim, N. A., Nordin, S. K., \& Buyong, S. Z. (2015). Understanding the Halal Concept and the Importance of Information on Halal Food Business Needed by Potential Malaysian Entrepreneurs. International Journal of Academic Research in Business and Social Sciences, 5(2), 170-180.

Balog, A. M., Baker, L. T., \& Walker, A. G. (2014). Religiosity and spirituality in entrepreneurship: A review and research agenda. Journal of Management, Spirituality \& Religion, 11(2), 159186. doi: 10.1080/14766086.2013.836127

Bellò, B., Mattana, V., \& Loi, M. (2018). The power of peers: A new look at the impact of creativity, social context and self-efficacy on entrepreneurial intentions. International Journal of Entrepreneurial Behavior \& Research, 24(1), 214-233. doi: 10.1108/IJEBR-07-2016-0205

Bellu, R. R., \& Fiume, P. (2004). Religiosity and Entrepreneurial Behaviour: An Exploratory Study. The International Journal of Entrepreneurship and Innovation, 5(3), 191-201. doi: $10.5367 / 0000000041513411$

Bjørner, T., Kofoed, L. B., \& Bruun-Pedersen, J. R. (2012). Creativity in Project Work-Students' Perceptions and Barriers. International Journal of Engineering Education, 28(3), 545-553.

Bustamam, U. S. A. (2012, July 26). Growth Strategy of Malay Entrepreneurs - Challenges and Opportunities: A Malaysian Case. Paper presented at the Asian Business and Management Conference, Osaka, Japan. Retrieved from http://ddms.usim.edu.my/handle/ $123456789 / 5812$

Carr, J. C., \& Sequeira, J. M. (2007). Prior family business exposure as intergenerational influence and entrepreneurial intent: A Theory of Planned Behavior approach. Journal of Business Research, 60(10), 1090-1098. doi: 10.1016/j.jbusres.2006.12.016

Carson, D., \& Gilmore, A. (2000). SME marketing management competencies. International Business Review, 9(3), 363-382. doi: 10.1016/S0969-5931(00)00006-8

Dewi, A. C. E., \& Dhewanto, W. (2012). Key Success Factors of Islamic Family Business. Procedia - Social and Behavioral Sciences, 57, 53-60. doi: 10.1016/j.sbspro.2012.09.1157

Drucker, P. (2014). Innovation and Entrepreneurship. London: Routledge.

Dyer, J. H., Gregersen, H. B., \& Christensen, C. (2008). Entrepreneur behaviors, opportunity recognition, and the origins of innovative ventures. Strategic Entrepreneurship Journal, 2(4), 317-338. doi: 10.1002/sej.59

Edoho, F. M. (2016). Entrepreneurship paradigm in the new millennium. Journal of Entrepreneurship in Emerging Economies, 8(2), 279-294. doi: 10.1108/JEEE-08-20150043

Edwards-Schachter, M., García-Granero, A., Sánchez-Barrioluengo, M., Quesada-Pineda, H., \& Amara, N. (2015). Disentangling competences: Interrelationships on creativity, innovation and entrepreneurship. Thinking Skills and Creativity, 16, 27-39. doi: 10.1016/j.tsc.2014.11.006

Falck, O., Heblich, S., \& Luedemann, E. (2012). Identity And Entrepreneurship: Do Peers At School Shape Entrepreneurial Intentions? Small Business Economics, 35(2), 1-21.

Fard, M. H., \& Amiri, N. S. (2018). The effect of entrepreneurial marketing on halal food SMEs performance. Journal of Islamic Marketing, 9(3), 598-620. doi: 10.1108/JIMA-12-20160097

Fayolle, A., \& Gailly, B. (2008). From craft to science: Teaching models and learning processes in entrepreneurship education. Journal of European Industrial Training, 32(7), 569-593. (world). doi: 10.1108/03090590810899838 
Fitzsimmons, J. R., \& Douglas, E. J. (2011). Interaction between feasibility and desirability in the formation of entrepreneurial intentions. Journal of Business Venturing, 26(4), 431-440. doi: 10.1016/j.jbusvent.2010.01.001

Fornell, C., \& Larcker, D. F. (1981). Structural Equation Models with Unobservable Variables and Measurement Error: Algebra and Statistics. Journal of Marketing Research, 18(3), 382-388.

Guerrero, M., Rialp, J., \& Urbano, D. (2008). The impact of desirability and feasibility on entrepreneurial intentions: A structural equation model. International Entrepreneurship and Management Journal, 4(1), 35-50.

Gümüsay, A. A. (2015). Entrepreneurship from an Islamic Perspective. Journal of Business Ethics, 130(1), 199-208. doi: 10.1007/s10551-014-2223-7

Guzmán, J., \& Javier Santos, F. (2001). The booster function and the entrepreneurial quality: An application to the province of Seville. Entrepreneurship \& Regional Development, 13(3), 211-228. doi: 10.1080/08985620110035651

Hair, J. F., Sarstedt, M., Hopkins, L., \& Kuppelwieser, V. G. (2014). Partial least squares structural equation modeling (PLS-SEM). European Business Review, 26(2), 106-121. doi: 10.1108/EBR-10-2013-0128

Hechavarria, D., Bullough, A., Brush, C., \& Edelman, L. (2019). High-Growth Women's Entrepreneurship: Fueling Social and Economic Development. Journal of Small Business Management, 57(1), 5-13. doi: 10.1111/jsbm.12503

Hisrich, R. D., Peters, M. P., \& Shepherd, D. A. (2002). Entrepreneurship. New York: McGrawHill.

Hoque, N., Mamun, A., \& Mamun, A. M. A. (2014). Dynamics and traits of entrepreneurship: An Islamic approach. World Journal of Entrepreneurship, Management and Sustainable Development, 10(2), 128-142.

Ireland, R. D., Hitt, M. A., \& Sirmon, D. G. (2003). A Model of Strategic Entrepreneurship: The Construct and its Dimensions. Journal of Management, 29(6), 963-989.

Karimah, I. (2019). Is Indonesia ready for halal certification obligation? The Jakarta Post. Retrieved October 16, 2019, from https://www.thejakartapost.com/academia/2019 /06/12/is-indonesia-ready-for-halal-certification-obligation.html

Kline, R. B. (2011). Convergence of Structural Equation Modeling and Multilevel Modeling. In M. Williams \& W. Vogt (Eds.), The SAGE Handbook of Innovation in Social Research Methods (pp. 562-589). United Kingdom: SAGE Publications Ltd.

Krueger, N. (1993). The Impact of Prior Entrepreneurial Exposure on Perceptions of New Venture Feasibility and Desirability. Entrepreneurship Theory and Practice, 18(1), 5-21. doi: $10.1177 / 104225879301800101$

Kuehn, K. W. (2008). Entrepreneurial Intentions Research: Implications for Entrepreneurship Education. Journal of Entrepreneurship Education; Arden, 11, 87-98.

Liñán, Francisco. (2007). The role of entrepreneurship education in the entrepreneurial process. In Fayolle A. (Eds.), Handbook of Research in Entrepreneurship Education (pp. 230). UK: Edward Elgar.

Macko, A., \& Tyszka, T. (2009). Entrepreneurship and Risk Taking. Applied Psychology, 58(3), 469-487. doi: 10.1111/j.1464-0597.2009.00402.x

Moghavvemi, S., Hakimian, F., \& Tengk Feissal, T. M. F. (2012). Competitive Advantages Through IT Innovation Adoption by SMEs. Social Technologies Research Journal, 2(1), 24-39.

Muslim Majority Countries 2019. (2019). Retrieved October 16, 2019, from http:/worldpopulationreview.com/countries/muslim-majority-countries/ 
Okpara, F. O. (2007). The value of creativity and innovation in entrepreneurship. Journal of Asia Entrepreneurship, 3(2), 1-14.

Organisation for Economic Co-operation and Development (OECD). (2018). SME and Entrepreneurship Policy in Indonesia. Retrieved from http://www.oecd.org/publications /sme-and-entrepreneurship-policy-in-indonesia-2018-9789264306264-en.htm

Othman, R., Ahmad, Z. A., \& Zailani, S. (2009). The Effect of Institutional Pressures in the Malaysian Halal Food Industry. International Business Management, 3(4), 80-84.

Perkembangan Data Usaha Mikro, Kecil, Menengah (UMKM) dan Usaha Besar UBB) Tahun 2016-2017. (2019). Ministry of Cooperatives and SMEs of the Republic of Indonesia. Retrieved from http://www.depkop.go.id/uploads/laporan/1549946778_UMKM\% 202016-2017\%20rev.pdf

Rahman, R. A., \& Mohamed, Z. (2011). Malaysian Halal Food Entrepreneurs Perspective Towards Globalization - A Conceptual Framework. SSRN eLibrary. Retrieved from https://papers.ssrn.com/abstract $=1869683$

Rhee, K. S., \& White, R. J. (2007). The Emotional Intelligence of Entrepreneurs. Journal of Small Business \& Entrepreneurship, 20(4), 409-425. doi: 10.1080/08276331.2007.10593408

Riaz, Q., Farrukh, M., Rehman, S., \& Ishaque, A. (2016). Religion and Entrepreneurial Intentions: An Empirical Investigation. International Journal of Advanced and Applied Sciences, 3(9), 31-36. Retrieved from Social Science Research Network website: https://papers.ssrn.com/abstract $=2905520$

Sadri, A. (2012). Science-Driven Entrepreneurship in the Islamic World. International Journal of Information Science and Management, 8(1), 73-81.

Shapero, A., \& Sokol, L. (1982). The Social Dimensions of Entrepreneurship. SSRN eLibrary. Retrieved from https://papers.ssrn.com/abstract=1497759

Singh, S. K., \& Gaur, S. S. (2018). Entrepreneurship and innovation management in emerging economies. Management Decision, 56(1), 2-5. doi: 10.1108/MD-11-2017-1131

Soltanian, M., Zailani, S., Iranmanesh, M., \& Aziz, A. A. (2016). Motivations of SME entrepreneurs to become halalpreneurs. Journal of Science and Technology Policy Management, 7(2), 173-189. doi: 10.1108/JSTPM-07-2015-0023

Suparno, \& Saptono, A. (2018). Entrepreneurship Education and Its Influence on Financial Literacy and Entrpreneurship Skills in College. Journal of Entrepreneurship Education, 21(4), 1-11.

Talib, M. S. A., Bakar, A. H. A., \& Too, A. C. (2019). Conceptualizing the Implementation of Halal Food Certification: An Institutional Theory Perspective. In F. Hassan, I. Osman, E. S. Kassim, B. Haris, \& R. Hassan (Eds.), Contemporary Management and Science Issues in the Halal Industry (pp. 385-393). Singapore: Springer

Thomson Reuters. (2018). State of the Global Islamic Economy Report 2018/19. Retrieved from https://haladinar.io/hdn/doc/report2018.pdf

Tyszka, T., Cieślik, J., Domurat, A., \& Macko, A. (2011). Motivation, self-efficacy, and risk attitudes among entrepreneurs during transition to a market economy. The Journal of SocioEconomics, 40(2), 124-131. doi: 10.1016/j.socec.2011.01.011

Tyszka, T., \& Zaleskiewicz, T. (2006). When Does Information about Probability Count in Choices Under Risk? Risk Analysis, 26(6), 1623-1636. doi: 10.1111/j.1539-6924.2006.00847.x

Vargas-Hernández, J. G., Noruzi, M. R., \& Sariolghalam, N. (2010). An Exploration of the Affects of Islamic Culture on Entrepreneurial Behaviors in Muslim Countries. Asian Social Science, $6(5), 120-127$. 
Wang, Y.-M., \& Lin, Y.-S. (2016). Determinants of Internet Entrepreneurship Intentions among Business School Students. International Journal of Information and Education Technology, 6(10), 754-758. doi: 10.7763/IJIET.2016.V6.787

Zampetakis, L. A., \& Moustakis, V. (2006). Linking creativity with entrepreneurial intentions: A structural approach. The International Entrepreneurship and Management Journal, 2(3), 413-428. doi: 10.1007/s11365-006-0006-z 